\title{
A posztoperatív keringésváltozások jelentősége a májsebészetben
}

\author{
Koós Olivér oh. - Kovács Tibor dr. - Fülöp András dr. - Pekli Damján dr. \\ Ónody Péter dr. - Lukovich Péter dr. - Harsányi László dr. \\ Kupcsulik Péter dr. - Hahn Oszkár dr. - Szijártó Attila dr.
}

Semmelweis Egyetem, Általános Orvostudományi Kar, I. Sebészeti Klinika, Budapest

\begin{abstract}
A máj rendhagyó keringéséért két afferens (arteria hepatica, vena portae) és egy efferens rendszer (venae hepaticae) felelős. Speciális vérellátásának köszönhetően az akut, izolált - szelektíven egy-egy érképletet érintő - vascularis okklúziók eltérő, életet veszélyeztető klinikopatológiai tünetegyütteshez vezethetnek, ezért azonnali felismerésük elengedhetetlen a máj állapota, illetve a beteg túlélésének szempontjából egyaránt. Akut keringészavarok kialakulásával elsősorban májmútétek kapcsán kell számolnunk. Az adekvát terápia mielőbbi megkezdése szempontjából kiemelten fontos a kóros keringési állapotok sajátosságainak pontos ismerete. Jelen tanulmány célja a szelektív posztoperatív keringési anomáliák etiológiájának, illetve tünettanának bemutatása, továbbá javaslat megfogalmazása a diagnosztikai lépések és a lehetséges terápia terén klinikai esetek ismertetése alapján. A szerzők bemutatják a májsebészetben használatos vascularis kirekesztés (Pringle-manőver) okozta ischaemiás-reperfúziós májkárosodást is. Orv. Hetil., 2015, $156(48), 1938-1948$
\end{abstract}

Kulcsszavak: arteria hepatica, májkeringés, májreszekció, vena hepatica, vena portae

\section{The importance of postoperative circulatory alterations in hepatic surgery}

There are two afferent (hepatic artery, portal vein) and one efferent (hepatic veins) systems responsible for the unique circulation of the liver. Given this special form of vasculature, acute, isolated (i.e. involving selectively one particular vessel) vascular occlusions may lead to different, however still life threatening conditions. Hence, it is essential to recognize these anomalies in order to preserve the healthy state of both the liver and the patient's lives. Acute circulatory failures are dominantly associated with liver surgery. Adequate therapy can only be provided promptly, if the clinician is well aware of the peculiarities of these conditions. The aim of this study is to overview the etiology and symptoms of these clinical conditions; furthermore to offer technical proposals for the required diagnostic and therapeutical steps via case reports. Furthermore, hepatic injury, caused by ischemia-reperfusion secondary to total vascular occlusion (Pringle maneuver) used in hepatic surgery is outlined.

Keywords: hepatic artery, hepatic vein, liver circulation, liver resection, portal vein

Koós, O., Kovács, T., Fülöp, A., Pekli, D., Ónody, P., Lukovich, P., Harsányi, L., Kupcsulik, P., Hahn, O., Szijártó, A. [The importance of postoperative circulatory alterations in hepatic surgery]. Orv. Hetil., 2015, 156(48), $1938-1948$.

(Beérkezett: 2015. augusztus 27.; elfogadva: 2015. szeptember 26.)

\section{Rövidítések}

ALT = alanin-aminotranszferáz; AST $=$ aszpartát-aminotranszferáz; $\mathrm{BCS}=$ Budd-Chiari-szindróma; $\mathrm{BE}=$ (base excess) bázisfelesleg; $\mathrm{CT}=$ komputeres tomográfia; eGFR = becsült glomerulusfiltrációs ráta; ERCP = endoszkópos retrográd cholangiopancreatographia; FLR $=$ (future liver remnant) posztreszekciós májtömeg; GGT = gamma-glutamiltranszferáz; HGF = (hepatocyte growth factor) hepatocytanövekedési faktor; $\mathrm{LMWH}=$ (low molecular weight heparin) alacsony molekulasúlyú heparin; MARS $=$ (molecular adsorbent recircu- 
lating system) májpótló kezelés; $\mathrm{MOF}=($ multi organ failure $)$ többszervi elégtelenség; $\mathrm{NE}=$ nemzetközi egység; $\mathrm{OAC}=$ orális antikoaguláns; PET = pozitronemissziós tomográfia; $\mathrm{pH}=$ (power of hydrogen) kémhatás; SIRS = (systemic inflammatory response syndrome) szisztémás gyulladás szindróma; stB = standard bikarbonát; WBC $=$ (white blood cell count $)$ fehérvérsejtszám

A máj nyugalomban a teljes perctérfogatból csaknem 25\%-ban részesül, azaz több mint $1 \mathrm{ml}$ vér jut minden gramm májparenchymára [1]. E jelentôs véráramlást intrinsic (autoreguláció, metabolikus kontroll) és extrinsic (neuralis, humorális) mechanizmusok által szorosan szabályozva - a vena portae (75\%) és az arteria hepatica (25\%) rendszere biztosítja. A máj kettős vérellátásának köszönhetően az ischaemiás folyamatok megjelenése igen változatos, nagymértékben függ az elzáródott ér típusától (arteria bepatica, vena hepatica, vena portae, összetett), az elzáródás helyétől (distalis, proximális érszakasz), annak időbeliségétől (akut, krónikus), a kollaterális hálózat fejlettségétől.

Akut artériás keringészavar felléptével elsősorban májmütétek kapcsán (epeúti mútéti beavatkozások, májreszekció, májtranszplantáció), mint gyakran fatális kimenetelú, a májállomány elhalásával fenyegető szövődménnyel kell számolnunk. Ugyanakkor fontos megjegyezni, hogy az akcidentális érelzáródás mellett az 1970-es évek óta a tumorterápia [2] eszköztárának egyik elemét is jelenti a mesterségesen létrehozott artériás okklúzió, amely a hepatocellularis carcinomák tekintetében a mai napig fontos terápiás lehetőség.

$\mathrm{Az}$ akut portalis elzáródás képében megjelenő, Friedrich Wilhelm Zahn által leírt [3, 4], róla elnevezett pseudoinfarctus parenchymalis atrophiával jár együtt. Ennek ellenére necrosis nélküli szöveti elváltozás képében jelenik meg, miután az artériás perfúzió megléte és megnyíló kollaterálisok miatt nem beszélhetünk komplett anoxiáról, mint azt klasszikus infarktusok esetében látjuk. Az elváltozás hegesedéssel gyógyul $[5,6]$. A vena portae krónikus okklúziója mind fejlődési rendellenességek, mind tumoros progresszió eredménye lehet, ugyanakkor az utóbbi időben a vena portae szelektív elzárása, mint terápiás lehetőség a többlépcsős májreszekciók algoritmusában a funkcionális kapacitás növelésének (májregeneráció-indukció) tárházát nyitotta meg [7].

A vena hepatica áramlászavarait elsősorban a George Budd által 1845-ben felismert [8], majd Hans Chiari [9] által 1899-ben patológiailag a vena bepatica endophlebitisének leírt Budd-Chiari-szindróma képzi. A közepes-kis vénákra lokalizálódó keringészavarok a Stuart-Bras-szindróma nevet kapták. Nem tartozik definíciószerúen a fenti kórállapotokba a congestiv szívelégtelenségből származó vagy konstriktív pericarditis eredetû, illetve a (post)sinusoidalis elzáródásokból származó vénás keringési elégtelenség. Az ascitesszel kísért májelégtelenségbe torkolló kórkép részint akut életveszélyes állapotként, részben krónikus formában fordul elő, amely utóbbi krónikus forma fóként a Távol-Keleten, 45 év körüli nőkben jelenik meg nagyobb számban. Ezen esetben a vena cava inferior is érintett, míg az akut lefolyású, tisztán vena hepaticákra lokalizálódó elváltozás főként a nyugati országok fiatalabb (35 év körüli csúccsal) női populációját érintheti [10].

A posztoperatív állapotokban kialakuló, szelektíven egy-egy érre lokalizálódó akut keringésváltozások klinikai megjelenése különböző, azonnali felismerésük elengedhetetlen a máj, illetve a beteg túléléséhez.

Jelen tanulmány négy olyan eset kapcsán kívánja bemutatni a máj fent említett keringészavarait, amelyekre májsebészeti tevékenységgel foglalkozó sebészeti osztályon számítani lehet, és felismerése a helyesen megválasztott terápia, így a beteg túlélése szempontjából elengedhetetlen. Az első három eset kapcsán a különböző anatómiai képletek (arteria hepatica, vena hepatica, vena portae) szelektív posztoperatív elzáródásából fakadó ischaemiás elváltozások tünettana kerül bemutatásra. A negyedik esetben a májsebészetben rutinszerúen használt vascularis kirekesztés (Pringle-manőver) után fellépő ischaemiás-reperfúziós károsodást kívánjuk bemutatni.

\section{Esetbemutatások}

\section{Arteria hepatica sinistra keringészavara}

A 44 éves férfi anamnéziséből 5 éve ismert gastrooesophagealis refluxbetegség emelendő ki. A nyelőcső distalis részére terjedő, nyelészavarokat okozó adenocarcinoma miatt végeztük mütétjét, amelynek során mintegy gyermekökölnyi tumor volt tapintható a hiatus oesophagiban. A nagycseplesz haránt vastagbélról való leválasztását, a kiscseplesz mobilizálását, a truncus coeliacus és az arteria hepatica communis kipreparálását követően a gyomor, a nyelőcső distalis része és a kisgörbületi nyirokcsomók en bloc eltávolításra kerültek. Ezt követően, a tápcsatorna folytonosságának helyreállítására vég az oldalhoz oesophagojejunalis anastomosist képeztünk, valamint tápláló jejunostomia kialakítására került sor. A posztoperatív ellátás 1 . napján a beteg általános állapota hirtelen, drasztikus romlást mutatott. A betegnél hypotonia, tachycardia, metabolikus acidosis jelentkezett (pH: 7,28; laktát: $6 \mathrm{mmol} / \mathrm{L} ; \mathrm{BE}:-10 \mathrm{mmol} / \mathrm{L})$. A májtranszamináz-értékek jelentős emelkedése alapján (AST: $1728 \mathrm{U} / \mathrm{L} ;$ ALT: $2348 \mathrm{U} / \mathrm{L}$ ) a máj súlyos keringési zavara vetődött fel, amelynek igazolására CT-angiográfiára került sor. Az elvégzett CT-vizsgálat során a bal májlebenyben, a II-es, III-as szegmentum területén egy $60 \mathrm{~mm}$ maximális átmérőjü, térképszerű hipodenzitás ábrázolódott (1. ábra). Az arteria hepatica sinistra az eredésétól körülbelül 5 mm-re elzáródott, benne kontraszttelődés nem volt megfigyelhető. Az arteria hepatica dextra és a portalis rendszer keringése ugyanakkor megtartottnak bizonyult. Sürgősséggel reoperációra került sor. A has megnyitását követően a máj bal lebenyének foltos elhalása mellett (2. ábra) az arteria bepatica 

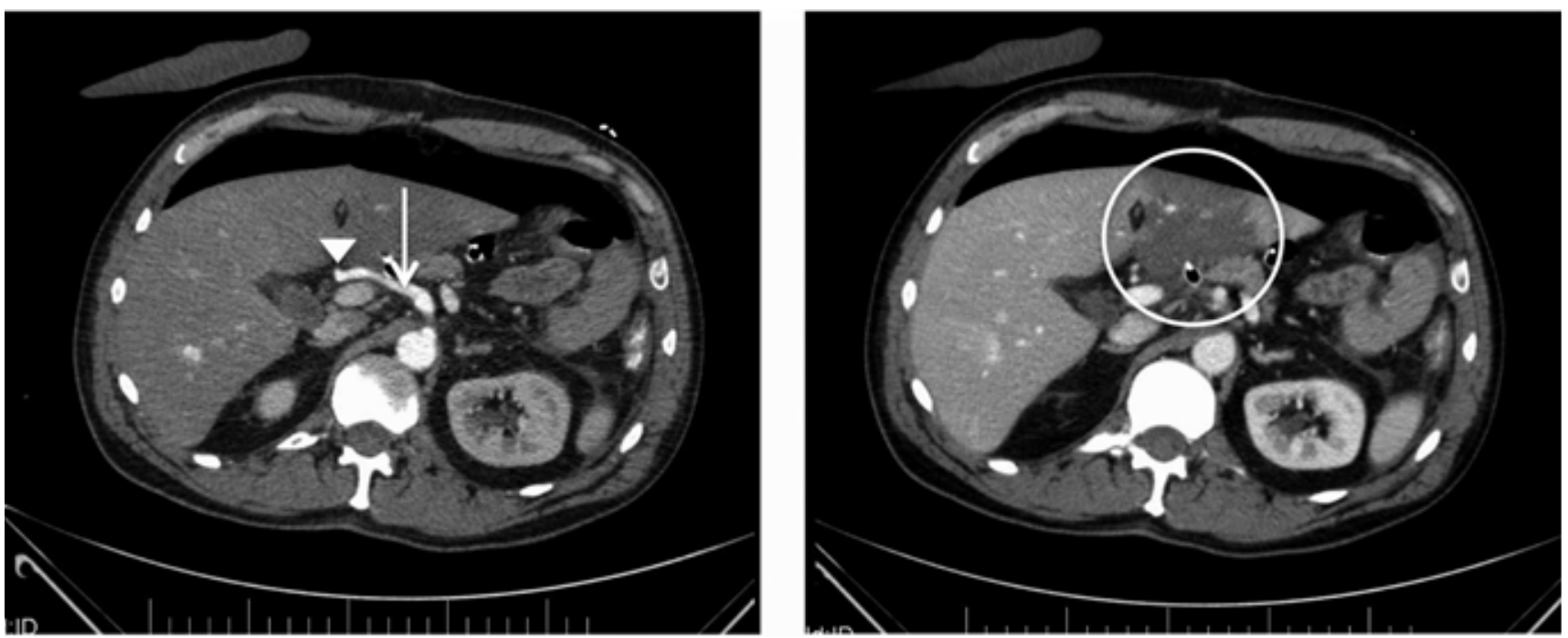

1. ábra

|CT-felvételek: a bal oldali angio-CT-felvételen látható a bal oldali arteria hepatica (nyíl) jelölt ponttól (nyílhegy) kezdődő telődéskiesése. A jobb oldali, vénás fázisú $(70 \mathrm{~s})$ képen a bal májlebeny II-es, III-as szegmentumának térképszerú hipodenzitása ábrázolódik (kör)

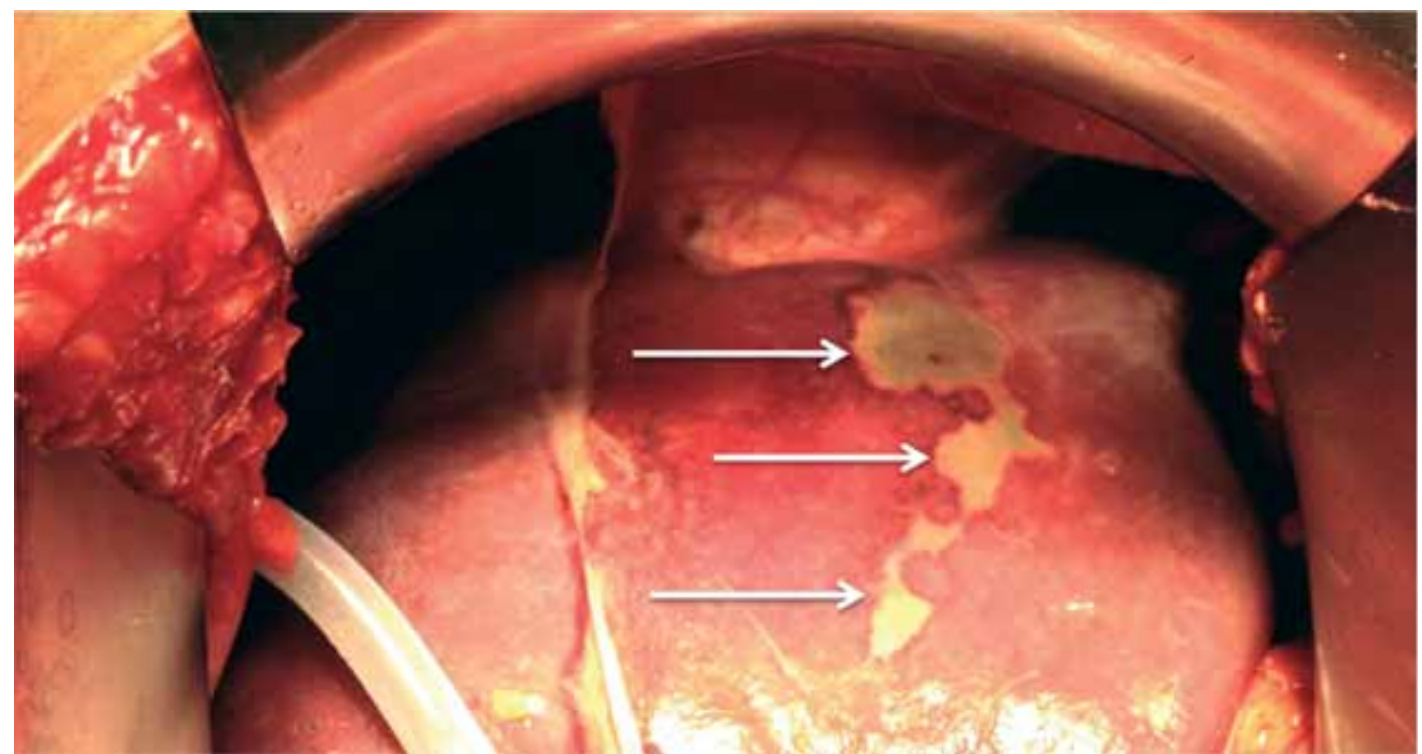

2. ábra

| Intraoperatív felvétel: a máj bal lebenyének kiterjedt, foltos elhalása látható (nyilak)

sinistra - feltehetően termikus sérülésére visszavezethető - elzáródása volt megfigyelhető. A máj mobilizálását követően a necroticus II-es, III-as szegmentumok eltávolításra kerültek. A mütétet követően a laborparaméterek gyors normalizálódása volt látható (3. ábra). A beteget kielégítő általános állapotban, láztalanul, rendezett passzázs mellett emittáltuk. Jelenleg jó általános állapotú, onkológiai kezelése zajlik.

\section{Vena portae thrombosis}

A 67 éves férfi beteg anamnéziséből hypertonia és krónikus glomerulonephritis emelendő ki. Hasi panaszok miatt kezdett gasztroenterológiai kivizsgálás, kolonosz- kópia során a flexura lienalisban stenotizáló, valamint az anusnyílástól $30 \mathrm{~cm}-\mathrm{re}$, a lumen háromnegyedét érintő, szinkron térfoglalások kerültek felismerésre. A szövettani mintavételek mindkét gócban adenocarcinomát igazoltak. A beteg kivizsgálása közben bélelzáródás lépett fel, ezért sürgős bal hemicolectomia és szigmareszekció történt Hartmann szerint. A kontroll posztoperatív CT-vizsgálat alapján a máj V-ös, VI-os, VIII-as szegmentumának találkozásánál egy $47 \mathrm{~mm}$ átmérőjü metachron metasztázis igazolódott. Sebészi, onkológiai konzílium véleménye alapján (borderline reszekabilitás) a tervezett májreszekció előtt a beteg négy ciklus kemoterápiát (bevacizumab+FOLFIRI: irinotecan+5-fluorouracil+folsav) kapott. Ennek lezárultával jobb oldali hepatolobec- 


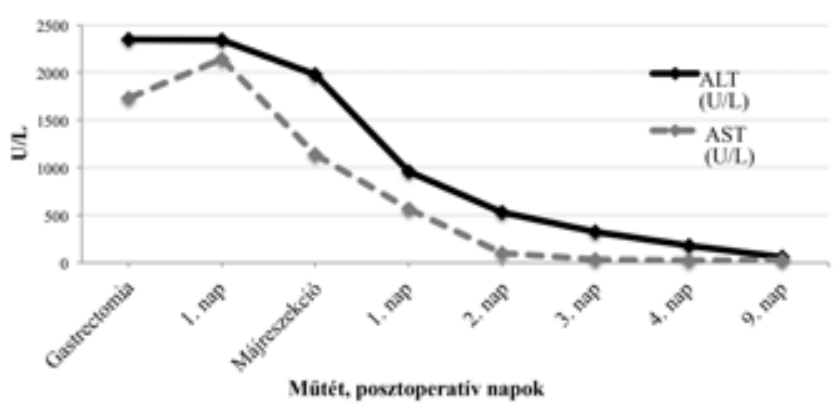

3. ábra $\quad$ A transzaminázértékek alakulása a posztoperatív napok függvényében

ALT $=$ alanin-aminotranszferáz

AST $=$ aszpartát-aminotranszferáz

tomiát hajtottunk végre Pringle-manőver 15 perces alkalmazása mellett. A jobb vena portae ág szelektív ellátását 4.0-ás monofil (Prolen ${ }^{\circledR}$, Ethicon) fonallal végeztük, amelyet követően mind a közös, mind a bal fötörzsben kellő kaliber mellett jó áramlás volt detektálható. A mútét alatt stabil hemodinamikai paramétereket mértünk, és a mútéti megterhelésnek megfelelő, enyhe metabolikus acidosis volt észlelhető (pH: 7,36; BE: -6,1 $\mathrm{mmol} / \mathrm{L}$ ). A posztoperatív szakban a betegnél hat óra leforgása alatt súlyosbodó, nem korrigálható metabolikus acidosis jelentkezett ( $\mathrm{pH}: 7,25 ; \mathrm{stB}: 17,6 \mathrm{mmol} / \mathrm{L}$; BE: $-10,8 \mathrm{mmol} / \mathrm{L}$; laktát: $10,2 \mathrm{mM} / \mathrm{L}$ ) közel normális ALT- és AST-értékek (119 U/L; $130 \mathrm{U} / \mathrm{L})$ mellett. A beteg intenzív terápiás kezelésre szorult, gépi lélegeztetését megszüntetni nem lehetett. A hirtelen fellépó állapotromlás etiológiájának tisztázására sürgős CT-vizsgálat történt. A vizsgálat tanúsága alapján a máj artériás keringése megtartott volt, azonban a vena portae közös törzsében, közvetlenül a vena lienalis beszájadzásánál induló, a lument egészében kitöltő és a megmaradt bal portaágig terjedő hypodenz thrombus volt látható, amely mellett lényegi keringés nem volt. A kialakult portalis nyomásemelkedés eredményeként a vena lienalis jelentős tágulata, a kollaterálisok megnyílása, splenomegalia volt detektálható (4. ábra). A fennálló, életet veszélyeztető állapot miatt újbóli mútét vált szüikségessé. A beavatkozás során heparinvédelemben, illetve hilaris és distalis vena portae kirekesztése mellett a jobb vena portae ág varratainak oldása után thrombectomiát végeztünk Fogarty szerint. Mind a vena mesenterica superior, mind a közös és bal vena portae lumene átjárhatóvá vált. A jobb véna fötörzsének ismételt varratát követően a bal porta ágrendszere jó kaliberrel telődött. A posztoperatív szakasz a továbbiakban zavartalanul telt, újabb szövődmény nem jelentkezett. A beteg laborparaméterei javuló tendenciát mutattak, acidosisa spontán korrigálódott. Az elvégzett kontroll-ultrahangvizsgálat szerint az arteria hepaticákból és a vena portae közös, illetve bal fötörzséból is jó Doppler-jel volt nyerhető. A thromboticus eseményre való tekintettel tartós LMWH-terápiát kezdtünk ( $2 \times 0,4 \mathrm{ml} 3800 \mathrm{NE}$ nadroparin). A kisfokú ascites és végtagi ödéma miatt vizelethajtó terápiát indítottunk (spironolacton $2 \times 100 \mathrm{mg}$, furosemid $1 \times 40 \mathrm{mg}$, káliumklorid $1 \times 1$ tabletta). A mútéteket követó 15 . napon a beteg jó általános állapotban, lázmentesen, reakció nélkül gyógyuló sebbel távozott. Onkológiai kezelése folyamatban van.

\section{Iatrogen vena hepatica sinistra stenosis}

A 67 éves nőbetegnél CT-vizsgálattal a máj jobb lebenyét kitöltő, $13 \mathrm{~cm}$ átmérôjú, vena hepatica mediát és sinistrát is komprimáló, azt széttoló cholangiocellularis carcinoma igazolódott. Klinikánkon a daganat méretének megkisebbítése céljából szelektív transarterialis embolisatiót végeztünk (5. ábra). Ezt követően a beteg 4
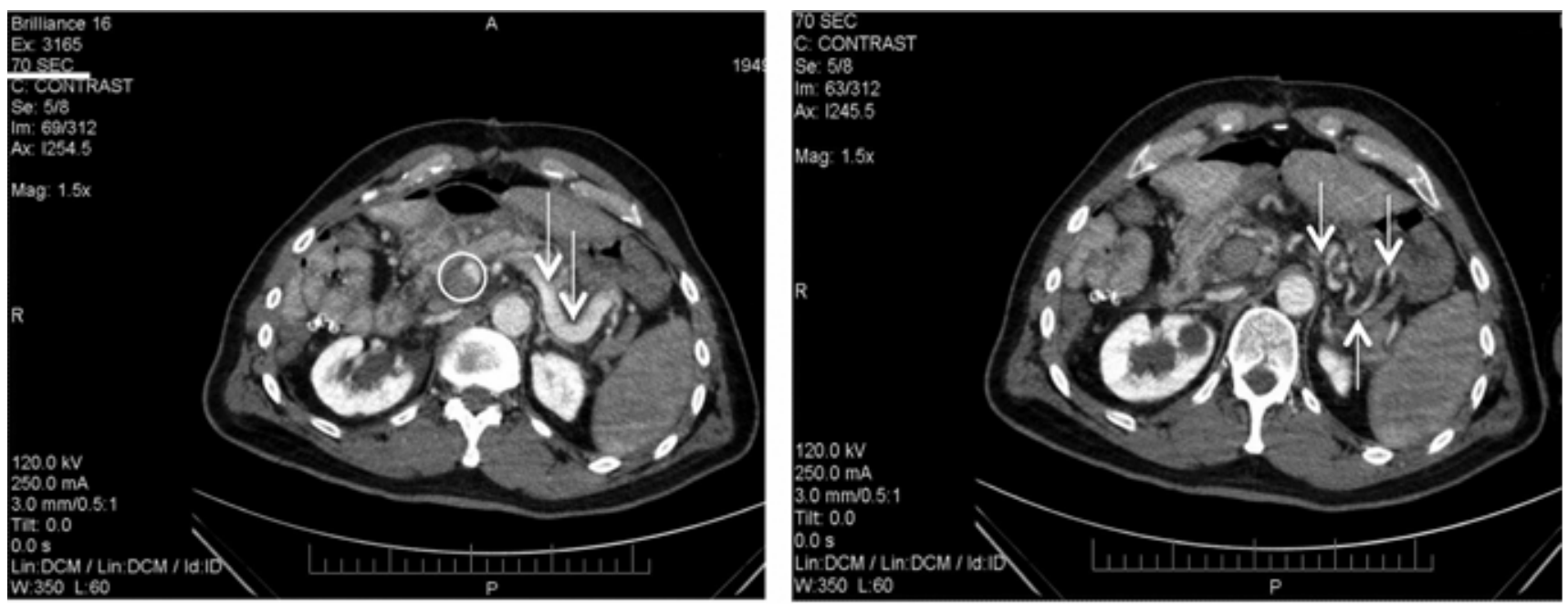

4. ábra $\quad$ A bal oldali képen a vena portae lumenének nagy részét kitöltő hipodenz telődéskiesés (kör), a pangás következtében nagymértékben kitágult lépvéna (nyilak) és splenomegalia látható. Jobb oldali kép: a pangás hatására megnyíló kollaterálisok (nyilak) 

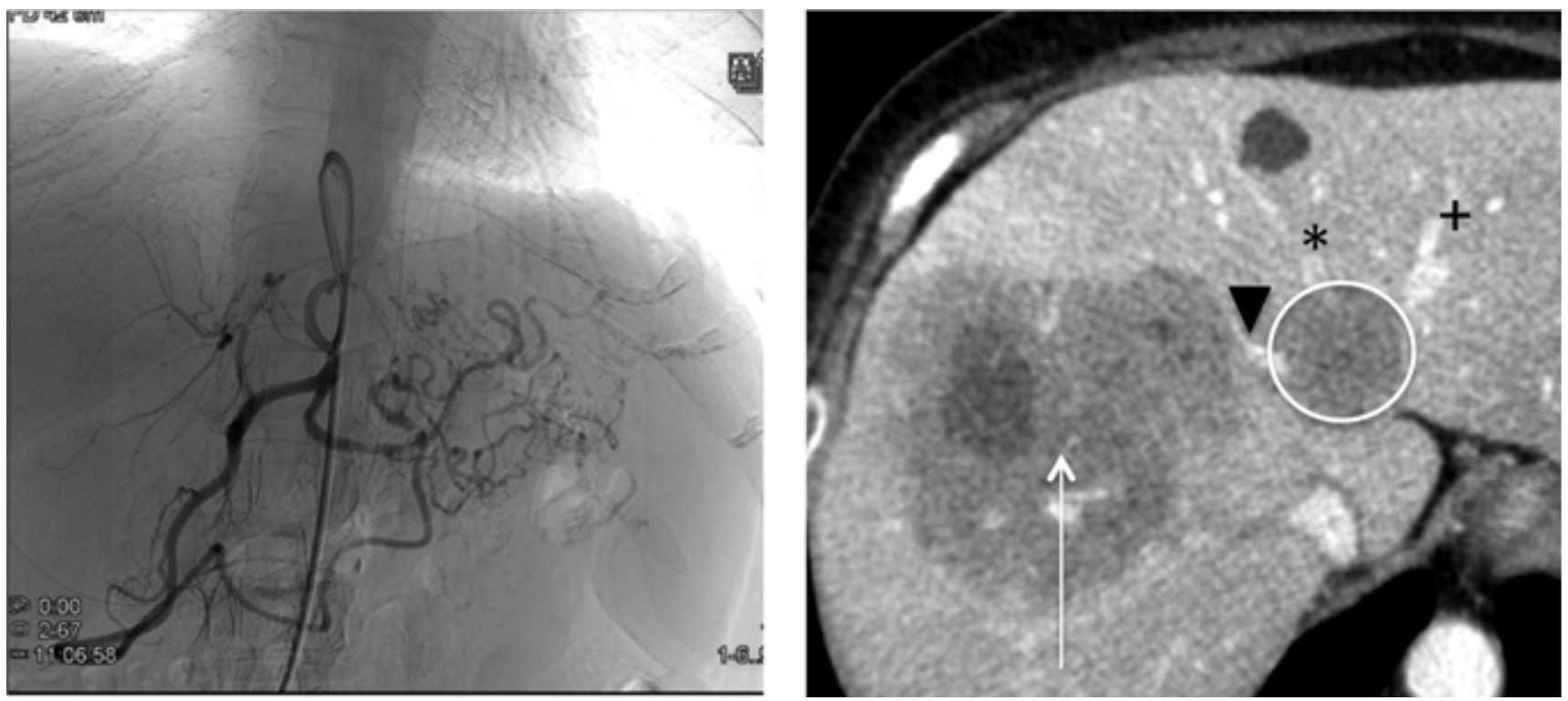

5. ábra

Bal oldalon: transarterialis embolisatio. Jobb oldalon: metastasis hepatis (nyíl), satellitametasztázis (kör) és a vena hepatica ágai (a középső jobb [ * és bal [nyílhegy] ága, illetve a bal vena hepatica [+]) látható

széria gemcitabin-cysplatin (GEM-DDP) neoadjuváns kemoterápiában részesült. A kontroll hasi CT-vizsgálat során a jelentős tumorregresszió jelei mellett, a vénás törzsek tumoros infiltrációja csökkent. A mútéti ellátás (kiterjesztett jobb hemihepatectomia) tervezése során, a visszamaradó máj kalkulált volumene (future liver remnant - FLR) elégségesnek (435 ml, 35\%) bizonyult. Előkészítését követően antibiotikum- és thromboprofilaxisban kiterjesztett jobb oldali hemihepatectomiát végeztünk. A szövődménymentes korai posztoperatív szak után az 5. napon a „fifty-fifty criteria” [11] kitételei alapján májelégtelenség jeleit észleltük (szérumbilirubin $>50$ $\mu \mathrm{M} / \mathrm{L}$, protrombinérték $<50 \%$ ) (6. ábra). Az elvégzett CT-vizsgálat alapján jelentős ascites volt látható, azonban egyértelmú keringési zavar nem volt detektálható.
Az emelkedő szérumbilirubin-értékek és súlyosbodó szeptikus állapot hátterében epeúti sérülést és cholangiogen infekciós forrást feltételeztünk, ezért ERCP-vizsgálatot végeztünk, ám ennek során epeúti akut megbetegedés nem igazolódott. A tovább romló májfunkciós paraméterek, májelégtelenség miatt MARS- (molecular adsorbent recirculating system) kezelést indítottunk, de ennek ellenére, az átmeneti javulást követően, a beteg állapota ismételten romlott. Az emelkedett gyulladásos paraméterek, időközben kialakult szeptikus sokk tünetei és ascitestenyésztés pozitivitása (MRSA) alapján nosocomialis infekció lehetősége merült fel, ezért reoperáció mellett döntöttünk. A mütét során a máj reszekciós felszíne melletti tályog ellátását végeztük. Ezután - átmeneti javulást követően - ismételten májelégtelenség tünetei jelentkeztek. Az elvégzett angio-CT-vizsgálat során a

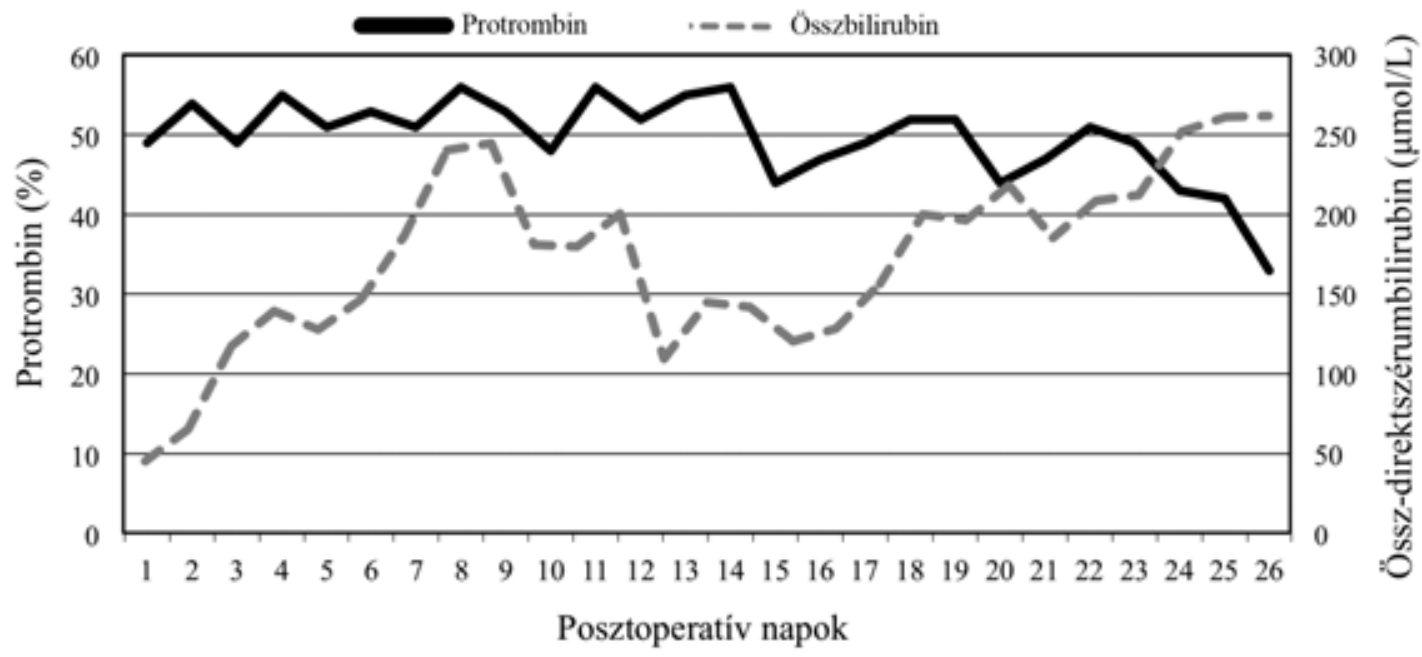

6. ábra $\quad$ A protrombin- és direktszérumbilirubin-értékek változásai a posztoperatív napok függvényében 

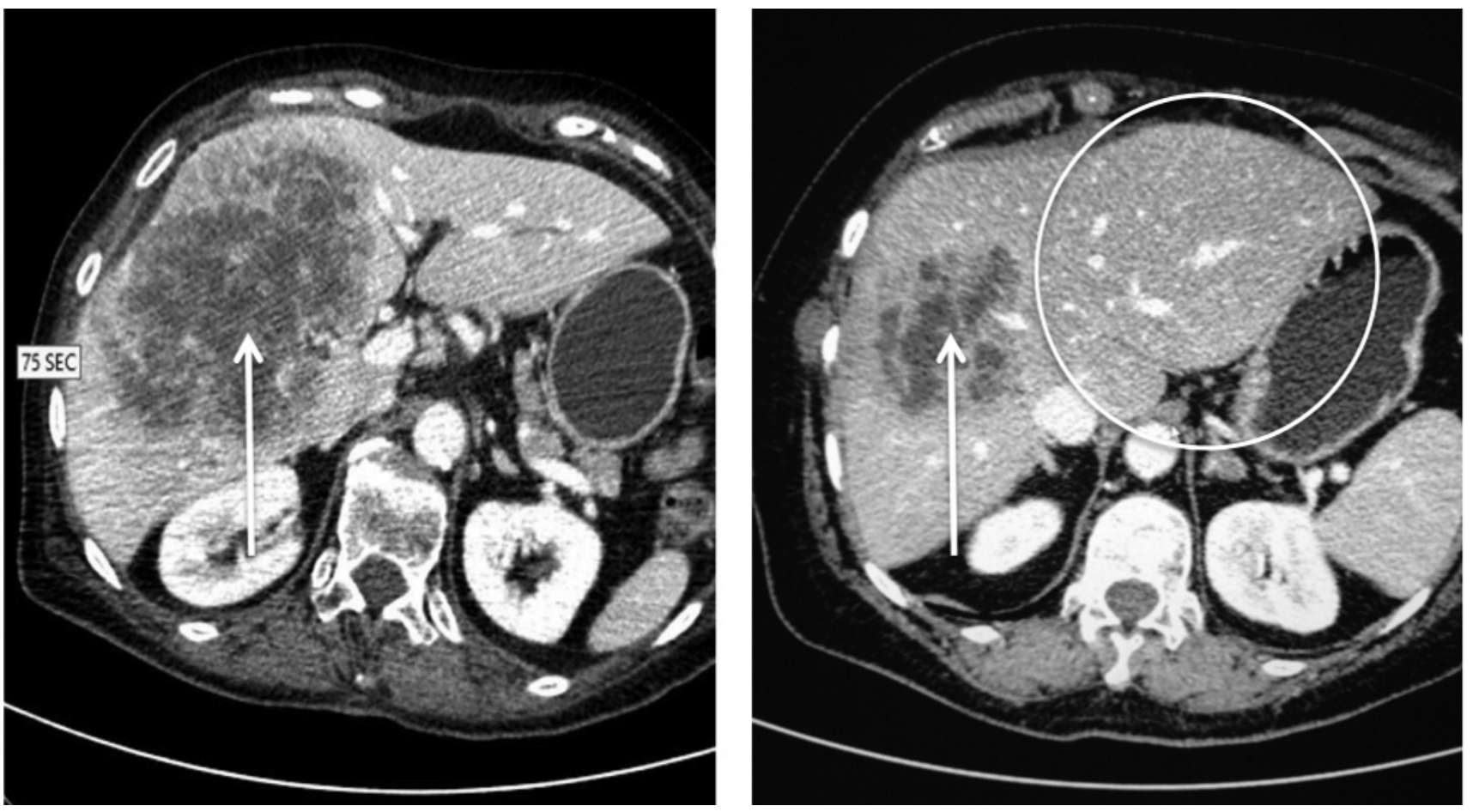

7. ábra

CT-felvételek. Bal oldali kép: vena portae ligatúra előtt: a jobb lebeny csaknem egészét érintő inhomogén térfoglalás (nyíl). Jobb oldali kép: ligatúra után négy hónappal - jobb lebeny atrophiája, a bal lebeny jelentős hypertrophiája (nyíl és kör)

bal vena hepatica egyértelmú, rövid szakaszú szúkülete igazolódott a vena cava inferiorba ömlése előtt. Revideálva korábbi véleményünket, a fentiek alapján a (hyperbilirubinaemiával és ascitesszel járó) májelégtelenséget a kezdetektől fogva fennálló, iatrogén eredetű, akut Budd-Chiari-szindróma kialakulásával magyaráztuk. Seldinger-módszerrel a vena hepatica sinistra tágítását, majd ezt követő stentelését végeztük, amelyet követően a stent migrációját észleltük az arteria pulmonalisba, amely hemodinamikai megingást nem jelentett. A beteg alvadási paraméterei fokozatosan romlottak, laktátacidosis, többszervi elégtelenség (multi organ failure - MOF) alakult ki. Az ismételt képalkotó vizsgálatok alapján felismert hasi tályogok többszörös oncotomiája történt, amelyet követően a beteg általános állapota tovább romlott, májelégtelensége tovább súlyosbodott, majd felső gastrointestinalis vérzés, szepszis, többszervi elégtelenség kialakulását követően a beteg meghalt.

\section{Pringle-manöpert követö reperfúziós szindróma}

A 60 éves nőbeteg kórelőzményében bal oldali emlődaganat szerepel: invazív ductalis carcinoma $\left(\mathrm{T}_{2} \mathrm{~N}_{2} \mathrm{M}_{1}\right.$; Her-2-pozitív; ER/PR 80\%) axillaris nyirokcsomóáttéttel és szoliter $(2 \mathrm{~cm})$ májmetasztázissal. Az onkológiai konzílium alapján a beteg neoadjuváns kezelésben részesült (4xTAC/taxoter, adriamicin, cyclophosphamid/), amely mellett regresszió nem volt észlelhető, így mastectomia és hónalji en bloc nyirokcsomó-dissectio történt. A beteg a továbbiakban radioterápiával kiegészített herceptin+docetaxel első vonalbeli kezelésben részesült. A kezelés alatt jelentős progressziót mutató $(8 \mathrm{~cm})$ májbeli térfoglalásból mintavétel történt, ami az emlődaganat áttétét igazolta. A képalkotók (PET-CT, CT) alapján további, távoli disszemináció nem volt detektálható, ugyanakkor a májtumor kiterjedése alapján a metasztázis sebészi ellátására jobb oldali hemihepatectomia jött számításba. Tekintettel az alacsony FLR-értékre, úgynevezett kétlépcsős májreszekció mellett döntöttünk. Az első mútét kapcsán a jobb vena portae ág lekötése, illetve cholecystectomia történt. Nyolc hetet követően, az elégségesnek ítélt regeneráció és további tumorprogressziót nem mutató CT-kép ellenére, az intraoperatív ultrahangvizsgálattal a IV-es szegmentum felé propagáló, azt részben érintő szatellitametasztázisok kerültek felismerésre, ezért a jobb hemihepatectomia nem volt kivitelezhető, viszont kiterjesztett jobb oldali hemihepatectomiára az FLR nem volt elegendő. Az onkológiai konzílium javaslata alapján további intravénás kemoterápia (gemcitabin) vált szükségessé. A négy hónappal később végzett kontroll-CT-vizsgálat távoli disszeminációt nem igazolt, ugyanakkor a szatellitametasztázisok méretbeli regresszióját ( $5 \mathrm{~mm}$ alattiak), a jobb lebeny atrophiáját és az I-IIIII-as szegmentumok további, jelentős (FLR 35,5\%) hypertrophiáját mutatta (7. ábra). A friss eredmények alapján a beteget kiterjesztett jobb oldali hemihepatectomia elvégzése céljából ismételten felvettük. Intermittáló vascularis kirekesztés mellett $(2 \times 25$ perces kirekesztés, közte 10 perc felengedés), a kiterjesztett jobb oldali hemihepatectomiának megfelelő vonalban, a ligamentum 


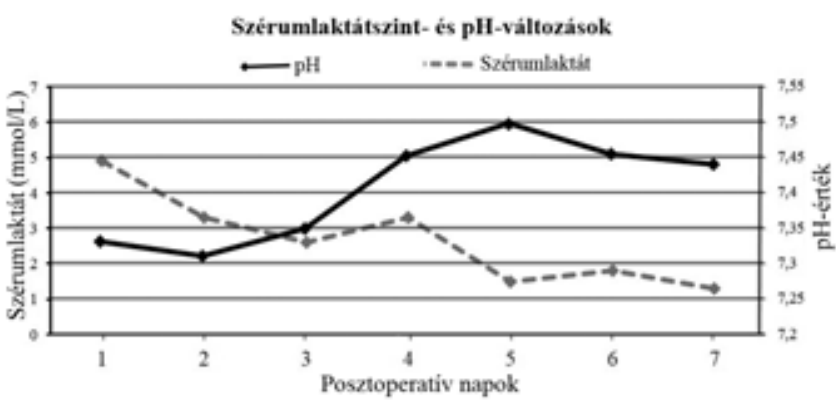

Protombin- és szérumbilirubinszint-változások

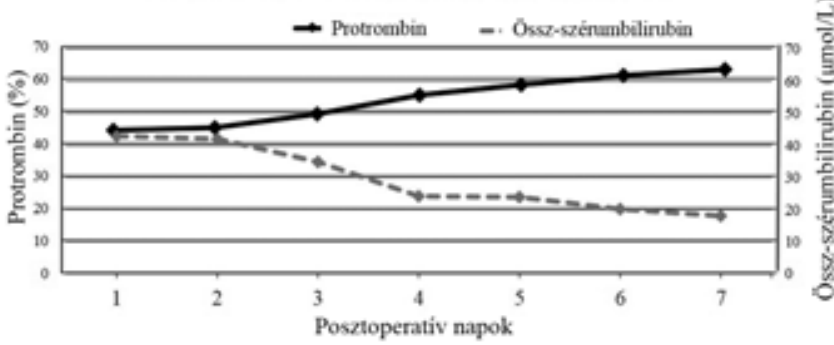

Transzaminázszint-változások

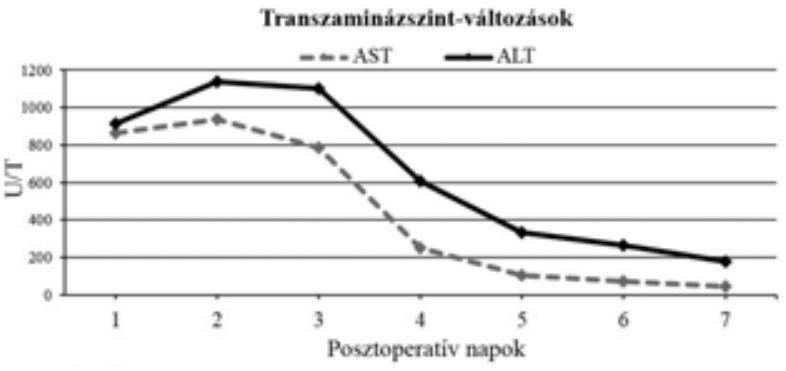

8. ábra

A szérumlaktátszint, $\mathrm{pH}$, protrombin-, szérumbilirubin-szint, illetve transzaminázértékek változásai a posztoperatív napok függvényében

ALT $=$ alanin-aminotranszferáz

AST $=$ aszpartát-aminotranszferáz

falciforme hepatis mellett, a II-es, III-as és I-es szegmentek meghagyásával reszekciót végeztünk. A korai posztoperatív időszakban a sav-bázis paraméterek acidosis irányába mutattak eltolódást, a beteg gépi lélegeztetésre szorult. Állapota a komplex kezelés ellenére sem javult, az első posztoperatív napon a beteg tudata továbbra is beszúkült maradt, szérumlaktátszintje emelkedett. Ezenkívül kiugró transzaminázszintek (AST: $864 \mathrm{U} / \mathrm{L}$; ALT: $915 \mathrm{U} / \mathrm{L}$; GGT: $144 \mathrm{U} / \mathrm{L})$, ödéma, csökkent diuresis (eGFR $60,6 \mathrm{ml} /$ perc/1,73 $\mathrm{m}^{2}$ ) és protrombinráta (51\%), illetve emelkedett gyulladásos (WBC: 26,24 G/L; CRP: $37,2 \mathrm{mg} / \mathrm{L}$ ) és szérumbilirubin-értékek (16,3 $\mathrm{mmol} / \mathrm{L})$ voltak megfigyelhetók (8. ábra). Ezen paraméterek a májelégtelenség kiterjesztett kritériumainak megfeleltek [12]. A gyorsan kialakult májelégtelenség etiológiájának tisztázására CT-angiográfiás vizsgálat történt, amely alapján a máj arterioportalis és vénás keringése kielégítőnek bizonyult, ugyanakkor a parenchyma inhomogén szerkezetűnek mutatkozott. Ez alapján felvetődött, hogy a korábbi onkológiai kezelések hatására jelentős károsodást elszenvedett májban ischae- miás-reperfúziós károsodás alakult ki az egyebekben tolerálható átmeneti vascularis kirekesztés hatására, amely potenciálisan felelőssé tehető a fennálló májelégtelenségért. Konzervatív kezelés mellett a kezdeti májelégtelenségre utaló paraméterek egy hét alatt normalizálódtak, így a beteg a felvételétől számított 14. napon további szövődményektől mentesen távozott.

\section{Megbeszélés}

A máj rendhagyó keringéséért két afferens (arteria bepatica, vena portae) és egy efferens rendszer (venae hepaticae) felelős. Speciális vérellátásának köszönhetően az akut, izolált - szelektíven egy-egy érképletet érintő - vascularis okklúziók eltérő, életet veszélyeztető klinikopatológiai tünetegyütteshez vezethetnek.

A máj említett kettős afferens vérellátásának ellenére, az arteria hepatica (amely a máj vérellátásának mindössze 25\%-át biztosítja) elzáródása gyors és súlyos állapotromláshoz vezethet. Az okklúzió eredete alapján sokféle lehet. Az eltérő incidenciával (11-32\%) [13] jelentkező, különböző kiterjedésú májnecrosishoz vezető arteria hepaticák önálló vagy epeutakkal kombinált elzáródása gyakran laparoszkópos cholecystectomia kapcsán alakul ki. A laparoszkópos cholecystectomia mellett, májtranszplantáció során észlelt artériás anomáliák, varrattechnikai nehézségek is jelentős szerepet kapnak, amelyek az élődonoros transzplantációk kapcsán még nagyobb számban fordulnak elő. Mivel transzplantáció során a májkárosodás hátterében - a varrat technikai szövődményeként - számos más ok is állhat (akut rejekció, nem funkcionáló graft), ezért a megjelenő tünetek esetén rendkívül fontos a helyes differenciáldiagnosztika.

A máj artériás ellátásának kiemelt feladata, hogy oxigénben dús vérrel egészítse ki a portalis rendszerből a sinusoidokba áramló, magas nutriens tartalmú vért. Ennek zavara esetén az oxigénkínálat csökkenése a sejtmetabolizmus károsodáshoz vezet. A celluláris energiaszint (ATP) csökkenésének következtében először az artériás ellátástól legtávolabb eső (Rappaport-féle májacinusmodell III. zóna) hepatocyták nekroapoptotikus pusztulása következik be (centrilobularis necrosis). Ez a folyamat az idő előrehaladtával a többi zóna sejtjeire is kiterjed, így a májparenchyma jelentős károsodása alakul ki. Könnyen belátható, hogy amíg az oxigéndús vér útjában álló akadály meg nem szűnik - ami általában jelentôs késéssel történik meg -, a májparenchyma progresszív pusztulása folytatódik. A kóros helyzet korai felismerésének fontossága abban rejlik, hogy minél hamarabb vetünk véget az ischaemiának, annál kisebb lesz az elveszített májtömeg. A legjellemzőbb tünetek a transzaminázszintek igen jelentős kiugrása, láz, esetleg szeptikus lázmenet, acidosis. Fontos tényező, hogy az epeutak vérellátása kizárólag az arteria hepatica rendszeréből ered, így gyakran számolni kell az epeutak vérellátásának kiesésére visszavezethető késői epesipollyal vagy súlyos biliaris peritonitis megjelenésével is [14]. Képalkotó eljárásokkal (CT-angiográfia, 
Doppler-ultrahang, angiográfia) általában felismerhető az artéria okklúziója, illetve megemlítendő, hogy egy már elkésett pillanatban, a natív hasi röntgenfelvételen időnként látható hepaticus/perihepaticus gázbuborékok is árulkodhatnak a parenchymában zajló necrosisról [14].

A necrosis kiterjedése alapján szegmentreszekció vagy az egész májat érintő károsodás kapcsán májtranszplantáció lehet a megoldás. A transzplantált betegek esetén a retranszplantáció látszik kielégítő terápiának.

A vena portae okklúziónak klinikai szempontból akut és krónikus formáit különböztetjük meg. Hátterében leggyakrabban thrombosis, illetve a portalis rendszer valamely ágát involváló térfoglaló folyamat áll. Míg az esetek 60\%-ában a thrombosis hátterében valamilyen szisztémás prothromboticus állapotot találunk (thrombophilia, myeloproliferativ betegség), addig a maradék 40\%-ban lokális tényezők (helyi gyulladásos folyamat, a vena portae rendszer sérülése, hasüregi szervet érintő daganat, cirrhosis) vezetnek a portalis thrombus kialakulásához [15, 16]. Tekintve, hogy bemutatott betegünk akut portalis thrombosis miatt igényelt sürgős beavatkozást, a továbbiakban ezt a kórformát tárgyaljuk részletesen.

Az akut vena portae thrombosist hirtelen fellépő hasi, néha lumbalis fájdalom, láz, ritkábban ascites és gastrointestinalis vérzés jellemzi. A fellépő tünetek kialakulásáért döntóen a mesenterialis pangás tehető felelössé. A posztoperatív vena portae thrombosis kiterjedését a Yerdel-beosztás [17] alapján osztályozhatjuk, amely szerint az elzáródás szintje jelentős mértékben befolyásolja az okklúzió következményeit. Abban az esetben ugyanis, ha a thrombus ráterjed a vena mesentericákra, illetve eléri a mesenterialis árkádokat, súlyos bélischaemia lép fel. Ennek oka az elfolyási akadály, ami reflexes arteriolaconstrictiót okoz. Abban az esetben, ha az obstrukció oldása rövid időn belül (okklúzió helyétől és fokától függően 0,5-48 óra) nem következik be, bélinfarktus alakulhat ki. A kórkép súlyosságának, illetőleg gyors terápiájának jelentőségét aláhúzza, hogy a necroticus belek késedelem nélküli reszekciója ellenére is $25-50 \%$-os mortalitással kell számolni [18]. A portalis elzáródás további fontos patofiziológiai következménye a portalis nyomásemelkedés, ami akár gastrointestinalis vérzéshez [19], illetve lépmegnagyobbodáshoz (akár léprupturához) vezethet [20]. Bemutatott esetünkben a lép megnagyobbodása mellett kollaterálisok bőséges hálózata volt megfigyelhető, amely végeredményben képes volt olyan mértékben csökkenteni a pangást, hogy a lép rupturája nem következett be (4. ábra).

Mivel a tünetek gyakran aspecifikusak és kezdetben kifejezetten enyhék lehetnek (hasi dystensio, progrediáló, diffúz hasi fájdalom, amely aránytalanul nagy a fizikális vizsgálat során észleltekhez - puha has - képest), a végső diagnózis felállítása gyakorta késedelmes. Ehhez hozzájárul az a tény, hogy - ellentétben a korábban részletezett artériás keringési zavarral - a vena portae okklúziója nem vezet a májparenchyma progresszív pusztulásához, annak ellenére sem, hogy a vena portae a máj keringésének közel 75\%-át képzi. Ennek hátterében részben az úgynevezett artériás „puffer” válasz (hepatic artery buffer response) jelenség áll, amelynek során a csökkenő portalis áramlás hatására az artériák tágulata jön létre, fokozva ezzel a máj artériás véráramlását. Másrészről a máj megtartottabb keringéséhez hozzájárulnak az igen gyorsan - napok alatt - kialakuló portoportalis anastomosisok, amelyek áthidalják az elzáródott érszakaszt. Mindezek következtében a hepaticus keringés gyakorlatilag kompenzált marad, emiatt többnyire nem jelentkeznek drámai májelégtelenségre utaló tünetek.

A vena portae keringészavarát a máj ugyan többnyire jól tolerálja, ám egyéb károsító noxák jelenléte mellett fennáll a lehetősége a tünetek súlyosbodásának, májelégtelenség kialakulásának. Jelen tanulmányban ismertetett eset kapcsán az alkalmazott Pringle-manőver során a beteg mája 25 perc ischaemiát szenvedett el. Ehhez társultan továbbá a parenchyma mintegy fele eltávolításra került a mútét során. Ennyi ischaemia a májat vulnerábilissá teszi, mivel energiatartalékait (ATP) kimeríti. Mindezek következtében a máj metabolikus funkciózavara jöhetett létre, így képtelen volt a mesenterialis pangásból adódó extrém mértékű laktátterhelés és metabolikus acidosis kompenzálására. A fentiek következtében a májkárosodás a kieső Cori-ciklus (amely a májban a laktátot ATP felhasználásával glükózzá alakítja, ezzel csökkentve a plazma laktátszintjét) következtében hozzájárult a tejsav-felhalmozódáshoz, a beteg állapotának romlásához. A vena portae thrombosis diagnosztikai lehetőségei közül kiemelendő a Doppler-ultrahang- és a CT-vizsgálat, amely modalitásokkal megbízhatóan vizsgálható az érintett erek áramlása, az intestinalis pangás mértéke és az esetlegesen kialakuló ascites. A CT-vizsgálat arra is alkalmas, hogy pontosan megmérjük az ér lumenében lévő thrombus méretét, kiterjedését, illetve képet ad az intestinum, a lép, a máj és a kollaterálisok állapotáról is.

$\mathrm{Az}$ akut vena portae thrombosis kezelésében konzervatív és invazív módszerek is rendelkezésre állnak. Kedvező terápiás eredménnyel jár, ha haladéktalanul elvégezzük az elzáródott véna thrombectomiáját. Ezzel az eljárással gyorsan megszüntethető a súlyos portalis hypertensio és megelőzhető az intestinalis necrosis, az eljárás jelentőségét azonban beárnyékolja a vénás thrombosis magas recidívarátája $[21,22]$. Abban az esetben, ha fennáll a mesenterialis infarktus lehetősége, mindenképpen szükséges az exploratív laparotomia. Amennyiben infarcerálódott bélszakaszokat találunk, azok gondos reszekciója végzendő. Mivel májnecrosis ebben az esetben általában nem következik be, ezért a máj mútéti ellátást többnyire nem igényel.

Ezenkívül logikus terápiás megfontolásnak tûnik a mélyvénás thrombosis analógiájára antikoaguláns kezelést kezdeni. Ugyanakkor egyelőre még nem állnak rendelkezésre kontrollált vizsgálatokból származó, az akut vena portae thrombosis kezelésében alkalmazott antikoaguláns terápiára vonatkozó adatok [23]. Mindazonáltal 
az ajánlások alapján a betegeknél minimum három hónapig tartó antikoaguláns terápiát kell indítani. Kezdetben a gyors hatás elérése érdekében LMWH- (low molecular weight heparin) kezelés választandó, később, amikor a beteg állapota stabilizálódott és nincs egyéb tervezett mútéti beavatkozás, áttérhetünk az orális antikoaguláns készítményekre (OAC). Amennyiben nem áll fenn ellenjavallat, azoknál a betegeknél, akiknél a thrombus ráterjedt a distalis mesenterialis vénákra is, és/vagy korrigálhatatlan thromboticus rizikófaktoraik vannak, az antikoaguláns kezelés hosszabb ideig alkalmazandó.

A vena hepatica elzáródása, szerzői nevén Budd-Chiariszindróma (BCS), a máj vénás kiáramlásának akadályozottságát jelenti, függetlenül annak szintjétől és mechanizmusától [16]. Lefolyás tekintetében az irodalom a Langlet-féle [24] klasszifikációt tartja meghatározónak, úgymint I-es típus (akut laesio okozta hepaticus kiáramlási akadály) - 7\%; II-es típus (krónikus laesio okozta hepaticus kiáramlási akadály) - 45\%; III-as típus (krónikus laesio akut rosszabbodása) - 48\%. A leggyakrabban thrombosis (75\%) [25], illetve mechanikai ok $(25 \%)[25,26]$ áll a kórkép hátterében. A thrombosisok hátterében a klasszikus véralvadási zavarok mellett irodalmi adatok szerint [27] a hosszú ideig tartó portalis kirekesztés okozta stasis is kóroki tényező lehet. A külső kompresszió okai közt szerepel - az általunk bemutatott esethez hasonlóan - a posztreszekciós (kiterjesztett jobb oldali hemihepatectomia) májlebenytorzió, „kinking” $[28,29,30]$, amire hajlamosít a hosszú extrahepaticus vena hepatica törzs $(1-7 \mathrm{~cm})$, meghosszabbodott bal vena hepatica (rapid tumornövekedés), valamint ligamentum triangulare sinistrum mobilizáció. Fontos kiemelni, hogy a iatrogén eredetú, akut BCS felismerése a májon végzett beavatkozásokat követően (májreszekciók, transzplantációk) nagy kihívást jelent, hiszen tünetei nem specifikusak, és fulmináns lefolyásának köszönhetően 24-48 órán belül letális kimenetelü [31]. Éppen ezért, ha az alább felsorolt tünetek lépnek fel a posztoperatív időszakban, az akut BCS lehetőségére gondolni kell. A (iatrogén eredetú) akut BCS tünetei közül a legjellemzőbbek a következők:

- hyperbilirubinaemia,

- coagulopathia,

- refrakter ascites.

A fentieken kívül jellemző lehet továbbá - májreszekciót vagy transzplantációt követően - a máj elhúzódó regenerációja (HGF), hepatomegalia, visszatérő hasi fájdalom, láz, illetve a portalis hypertensio részeként jelentkező mesenterialis pangás, splenomegalia, portocavalis söntök megnyílása is [32]. A folyamatok hátterében a máj szöveti mikrokeringésében bekövetkező változások állnak. Amint a vénás kiáramlás akadályozottá válik, a máj mikrocirkulációja zavart szenved. Az ischaemiás károsodások a portalis triászoktól legtávolabb eső, Rappaport-féle III-as jelentkezik elsóként. A csökkenő intracelluláris ATP-szint miatt a sejt normális múködését és ozmotikus állapotát fenntartó, nagy energiaigényű ion- pumpák $\left(\mathrm{Na}^{+} / \mathrm{K}^{+}\right.$ATP-áz, $\mathrm{Na}^{+} / \mathrm{Ca}^{2+}$ antiporter, $\mathrm{Na}^{+} / \mathrm{H}^{+}$ antiporter stb.) múködése zavart szenved, amelynek köszönhetően a sejtek duzzadnak. Ennek eredményeképpen a sinusoidokban a nyomás tovább nő, amelynek hatására a kialakuló folyadéktranssudatio hozza létre az ascitest. A mikrocirkulációs zavarnak köszönhetően a májban csökken a funkcionáló sejtek száma (következményes coagulopathia, hypoalbuminaemia lép fel), ennek eredményeképpen a máj folyamatos regenerációs stimulus alá kerül, amit jól mutat a szérum emelkedett HGF-szintje. Lényeges mozzanat, hogy minél erősebb a regenerációs stimulus, annál jelentősebben károsodik a máj mikrocirkulációja és sinusoidalis architektúrája, aminek következtében a bilirubinkiválasztás további jelentős zavart szenved [33]; ez hyperbilirubinaemia és sárgaság képében jelenik meg. Az imént részletezett folyamat gyorsan önrontó körré válik, így végül potenciálisan súlyos májelégtelenség kialakulásához vezethet.

A BCS ellátására Janssen és mtsai ajánlása alapján [34] szóba jövő kezelési lehetőségek között találjuk a gyógyszeres terápiát (antikoaguláns, diuretikum), szükség esetén paracentesissel kiegészítve, illetve az intervenciós technikákat (akut esetben direkt thrombolysis), illetve a transzplantációig áthidaló megoldásként a sebészi portoszisztémás sönt kialakítását. Amennyiben a májelégtelenség tünetei progrediálnak, a májtranszplantáció túnik az egyedüli megoldásnak.

További irodalmi adatok $[28,35]$ szerint az akut BCS korszerü ellátása a percutan transluminaris intervenció (ballon-angioplasztika, stentimplantáció). A fent bemutatott betegünk ellátása során is intervenciós eljárásra került sor, igazodva ezzel az irodalmi ajánlásokhoz, azonban betegünk esetében a megfelelöen pozicionált stent a beavatkozást követő időszakban elmozdult.

Míg a fentiekben a máj egyes afferens és efferens ereinek szelektív, iatrogén elzáródásából adódó kórképek kerültek megbeszélésre, nem szabad megfeledkezni a májsebészeti beavatkozások során gyakran elengedhetetlenül alkalmazott, több érre kiterjedő vascularis kirekesztés és a következetes ischaemia-reperfúziós károsodás jelentőségéről sem.

A máj speciális vérellátásából adódóan a májat érő trauma, a major májreszekciós mútét, illetve a transzplantáció elfogadhatatlanul nagy vérveszteséggel járhatnak. James Hogarth Pringle 1908-ban számolt be arról, hogy súlyos hasi traumát szenvedett betegeknél a ligamentum hepatoduodenale lekötésével eredményesen csökkentette a hasûri vérzést. Bár a posztoperatív időszakban mindegyik betegét elvesztette, a kontrollált kirekesztés alapjai széles körben elfogadottá váltak annak köszönhetően, hogy Ichio Honjo és Jean-Louis Lortat Jacob sikerrel hajtottak végre major májreszekciót a kirekesztés alkalmazása mellett. Kevésbé ismert tény, hogy Báron Jónás, magyar sebész már 1876-ban leírta a ligamentum hepatoduodenale átmeneti lekötésének vérzéscsillapító hatását. A nemzetközi irodalomban Pringle-manőverként ismert technika a ligamentum hepatoduodenale, képle- 
teinek kompressziója révén, a máj ischaemiás állapotához vezet. Mint azt korábban bemutattuk, a vértelenség a májsejtek energiacsökkenéséhez és következményes pusztulásához vezethet. A reperfúzió - bár elengedhetetlen a szövetek túléléséhez - a várttól eltérően, paradox módon fokozza a parenchyma károsodásának mértékét. A máj ischaemiás-reperfúziós szövetkárosodása korai és késői fázisra osztható [36]. A reperfúzió első 6 órájára tehető korai fázist az ischaemia és az ezt követő reperfúzió közvetlen sejtszintű következményei jellemzik. A májszövet redox-homeosztázisa gyorsan felborul, az oxidatív stressz hatására az energiatermelésükben károsodott máj- és a sinusoidalis endothelsejtekben súlyos ioneloszlási zavar lép fel, továbbá elégtelenné válik a szöveti mikrocirkuláció is. A késői fázisban ezzel szemben az immunrendszer aktiválódása válik a meghatározó tényezővé. A folyamatot a károsodott és aktivált sejtekből felszabaduló citokinek és kemokinek lokális koncentrációjának emelkedése vezeti be, amit a keringő leukocyták szöveti infiltrációja követ. A kitapadó fehérvérsejtek képesek a lokális gyulladás kiterjedését sokszorosára növelni, amely adott esetben az egész szervezetet érintő, generalizált reakcióvá (systemic inflammatory response syndrome - SIRS) válhat.

A fent leírt folyamatot számtalan kísérletben vizsgálják, azonban a pontos mechanizmus ma sem egészen tisztázott. Azt azonban tudjuk, hogy a kontrollált ischaemia biztonságosan használható mútéti eljárás.

A bemutatott eset kapcsán kétszer 25 perc „meleg” (normothermiás) ischaemia került alkalmazásra, 10 perces reperfúzióval, amely manővert a máj (és a beteg) az esetek döntő többségében jól tolerál, ugyanakkor a jelen esetismertetésben bemutatott páciensnél a májelégtelenség tünetei jelentkeztek. Ennek hátterében feltehetően a mütétet megelőzően alkalmazott, több széria kemoterápiás kezelés állhatott, amely kemoterápiás szerek számos mellékhatásainak egyike gyakran a hepatotoxicitas. További bizonyítékul szolgál, hogy a jelen esetben az alkalmazott vena portae okklúzió után a standard regenerációs idő ( 8 hét) kevésnek bizonyult, a máj igen lassú ütemű hypertrophiát mutatott, ami véleményünk szerint ugyancsak a kemoterápia mellékhatásának volt betudható.

Összességében tehát a Pringle-manőver ugyan nem veszélytelen, mégis csaknem nélkülözhetetlen eljárás vérveszteségének csökkentésére, föként kiterjesztett májmütétek, transzplantáció, illetve trauma esetén. Minden esetben fontos számításba venni az adott beteg anamnézisét, ugyanis a májparenchyma preoperatív állapota nagyban befolyásolja a máj ischaemiatoleranciáját és regenerációs képességét.

\section{Következtetések}

A májat érintő akut, iatrogén eredetű keringészavarok egymástól eltérő tünetekkel jelentkeznek, és felismerésüket nehezíti a tünetek aspecificitása is. Bármely, májon végzett beavatkozás után fellépő, a máj elégtelen múködésére utaló tünet vagy laboreredmény esetén azonban mindig gondolnunk kell esetleges májkeringési zavarokra. Hangsúlyozandó, hogy az érelzáródás felismerésének elmulasztásából adódó késlekedés akár a beteg életébe kerülhet, amit jól érzékeltet, hogy mind a négy, fentiekben bemutatott, akut vascularis történés életet veszélyeztető állapotnak bizonyult.

Anyagi támogatás: A közlemény az MTA Bolyai János Kutatási Ösztöndíj támogatásával készült.

Szerzői munkamegosztás: K. O., K. T., F. A., P. D., Ó. P.: Adatgyüjtés, cikkírás. H. L., K. P., H. O., L. P., Sz. A.: Klinikai adatszolgáltatás, cikkírás. A kézirat végleges verzióját valamennyi szerző elolvasta és jóváhagyta.

Érdekeltségek: A szerzőknek nincsenek érdekeltségeik.

\section{Irodalom}

[1] Bennink, R. J., Tulchinsky, M., de Graaf, W., et al.: Liver function testing with nuclear medicine techniques is coming of age. Semin. Nucl. Med., 2012, 42(2), 124-137.

[2] Madding, G. F., Kennedy, P. A., Sogemeier, E.: Hepatic artery ligation for metastatic tumor in the liver. Am. J. Surg., 1970, $120(1), 95-96$

[3] Zahn, F.: Experimentelle Erzeugung von Leber- und Lungeninfarkten. Zentralblatt für allgemeine Pathologie und pathologische Anatomie, 1897, 8, 860.

[4] Zahn, F. W.: Experimentelle Erzeugung von Leber- und Lungeninfarkten. Verh. Ges. Dtsch. Naturf. Aerty Braunschweig, 1897. pt. 2.

[5] Horrocks, P., Tapp, E.: Zahn's 'infarcts' of the liver. J. Clin. Pathol., 1966, 19(5), 475-478.

[6] Matsumoto, T., Kuwabara, N., Abe, H., et al.: Zahn infarct of the liver resulting from occlusive phlebitis in portal vein radicles. Am. J. Gastroenterol., 1992, 87(3), 365-368.

[7] De Santibañes, E., Clavien, P. A.: Playing play-doh to prevent postoperative liver failure: the "ALPPS" approach. Ann. Surg., 2012, 255(3), 415-417.

[8] Budd, G.: On congestion of the liver. In: Budd, G. (ed.): On the diseases of the liver. Blanchard \& Lea, Philadelphia, 1857.

[9] Chiari, H.: Über die selbständige Phlebitis obliterans der Hauptstämme der Venea hepaticae als Todesursache. Beiträge zur pathologischen Anatomie und zur allgemeinen Pathologie, Jena, 1899 .

[10] Valla, D. C.: Hepatic venous outflow tract obstruction etiopathogenesis: Asia versus the West. J. Gastroenterol. Hepatol., 2004, 19, S204-S211.

[11] Balzan, S., Belghiti, J., Farges, Q., et al.: The " $50-50$ criteria" on postoperative day 5: an accurate predictor of liver failure and death after hepatectomy. Ann. Surg., 2005, 242(6), 824-829.

[12] Schindl, M. J., Redhead, D. N., Fearon, K. C., et al.: The value of residual liver volume as a predictor of hepatic dysfunction and infection after major liver resection. Gut, 2005, 54(2), 289-296.

[13] Stewart, L., Robinson, T. N., Lee, C. M., et al.: Right hepatic artery injury associated with laparoscopic bile duct injury: incidence, mechanism, and consequences. J. Gastrointest. Surg., 2004, 8(5), 523-531.

[14] Tzakis, A. G., Gordon, R. D., Shaw, B. W. Jr., et al.: Clinical presentation of hepatic artery thrombosis after liver transplantation in the cyclosporine era. Transplantation, 1985, 40(6), 667-671. 
[15] Valla, D. C., Condat, B.: Portal vein thrombosis in adults: pathophysiology, pathogenesis and management. J. Hepatol., 2000, 32(5), 865-871.

[16] DeLeve, L. D., Valla, D. C., Garcia-Tsao, G.: Vascular disorders of the liver. Hepatology, 2009, 49(5), 1729-1764.

[17] Yerdel, M. A., Gunson, B., Mirza, D., et al.: Portal vein thrombosis in adults undergoing liver transplantation: risk factors, screening, management, and outcome. Transplantation, 2000, 69(9), 1873-1881

[18] Senzolo, M., Riggio, O., Primignani, M.: Vascular disorders of the liver: recommendations from the Italian Association for the Study of the Liver (AISF) ad hoc committee. Dig. Liver Dis., 2011, 43(7), 503-514.

[19] Lebrec, D., Bataille, C., Bercoff, E., et al.: Hemodynamic changes in patients with portal venous obstruction. Hepatology, 1983, $3(4), 550-553$.

[20] Zimmerman, D., Bell, W. R.: Venous thrombosis and splenic rupture in paroxysmal nocturnal hemoglobinuria. Am. J. Med., $1980,68(2), 275-279$.

[21] Menon, N. J., Amin, A. M., Mohammed, A., et al.: Acute mesenteric ischaemia. Acta Chir. Belg., 2005, 105(4), 344-354.

[22] Boley, S. J., Kaleya, R. N., Brandt, L. J.: Mesenteric venous thrombosis. Surg. Clin. North Am., 1992, 72(1), 183-201.

[23] Condat, B., Pessione, F., Denninger, M. H., et al.: Recent portal or mesenteric venous thrombosis: increased recognition and frequent recanalization on anticoagulant therapy. Hepatology, 2000, 32(3), 466-470.

[24] Langlet, P., Escolano, S., Valla, D., et al.: Clinicopathological forms and prognostic index in Budd-Chiari syndrome. J. Hepatol., 2003, 39(4), 496-501.

[25] Bezeaud, A., Denninger, M. H., Dondero, F., et al.: Hypercoagulability after partial liver resection. Thromb. Haemost., 2007, 98(6), 1252-1256.

[26] Pitre, J., Panis, Y., Belghiti, J.: Left hepatic vein kinking after right hepatectomy: a rare cause of acute Budd-Chiari syndrome. Br. J. Surg., 1992, 79(8), 798-799.
[27] Di Domenico, S., Rossini, A., Petrocelli, F., et al.: Recurrent acute Budd-Chiari syndrome after right hepatectomy: US color-Doppler vascular pattern and left hepatic vein stenting for treatment. Abdom. Imaging, 2013, 38(2), 320-323.

[28] Wang, J. K., Truty, M. J., Donobue, J. H.: Remnant torsion causing Budd-Chiari syndrome after right hepatectomy. J. Gastrointest. Surg., 2010, 14(5), 910-912.

[29] Sequeira, F. W., Weber, T. R., Smith, W. L., et al.: Budd-Chiari syndrome caused by hepatic torsion. Am. J. Roentgenol., 1981, 137(2), 393-394.

[30] Benesch, M., Urban, C., Deutschmann, H., et al.: Management of Budd-Chiari syndrome by hepatic vein stenting after extended right hepatectomy. J. Pediatr. Surg., 2002, 37(11), 1640-1642.

[31] Kupcsulik, P.: Portal hypertension. In: Fehér, J., Lengyel, G. (eds.): Hepatology. [Portalis hypertensio. In: Fehér, J., Lengyel, G. (szerk.): Hepatológia.] Medicina Könyvkiadó, Budapest, 2002. [Hungarian]

[32] Iwakiri, Ү.: Pathophysiology of portal hypertension. Clin. Liver Dis., 2014, 18(2), 281-291.

[33] Ninomiya, M., Shimada, M., Terashi, T., et al.: Sustained spatial disturbance of bile canalicular networks during regeneration of the steatotic rat liver. Transplantation, 2004, 77(3), 373-379.

[34] Janssen, H. L., Garcia-Pagan, J. C., Elias, E., et al.: Budd-Chiari syndrome: a review by an expert panel. J. Hepatol., 2003, 38(3), 364-371.

[35] Ninomiya, M., Ikeda, T.: Compressive stenosis of the left hepatic vein as a pathogenesis of postresectional liver failure: a case report. J. Med. Case Rep., 2010, 4, 163.

[36] Menger, M. D., Richter, S., Yamauchi, J., et al.: Role of microcirculation in hepatic ischemia/reperfusion injury. Hepatogastroenterology, 1999, 46(Suppl. 2), 1452-1457.

(Koós Olivér e-mail: oliver.koos@studiobp.hu)

Az Orvosi Hetilap egyes számai megvásárolhatók a Mediprint Orvosi Könyvesboltban.

Cím: Budapest V., Múzeum krt. 17. - Telefon: 317-4948 